\title{
CHEMICAL CONSTITUENTS OF THE WOOD FROM Zanthoxylum quinduense Tul. (Rutaceae)
}

\author{
Oscar Javier Patiño Ladino* y Luis Enrique Cuca Suárez \\ Departamento de Química, Facultad de Ciencias, Universidad Nacional de Colombia, Bogotá, KR 3045 03, Colombia. A.A. 14490
}

Recebido em 26/3/09; aceito em 5/1/10; publicado na web em 23/4/10

\begin{abstract}
Phytochemical investigation of the wood from Zanthoxylum quinduense Tul. allowed the isolation and identification of norchelerythrine, decarine, 6-acetonyldihydrochelerythrine, syringaresinol, evofilin $C, p$-hydroxybenzaldehyde, vanillic acid, a mixture of $\beta$-sitosterol, stigmasterol and campesterol and a mixture of saturated and unsaturated fatty acids, and their esters derivatives. The structures of the isolated compounds were elucidated by spectroscopic techniques and comparison with literature data and the mixture of sterols and fatty acids were identified by GC/MS. The antifungal activity of the ethanolic extract, fractions and pure compounds against Fusarium oxysporum f. sp. lycopersici was determined by bioautography. Evofilin $C$ and nochelerytrine were the only substances that present antifungal activity.
\end{abstract}

Keywords: Zanthoxylum quinduense; benzophenanthridine alkaloids; antifungal activity.

\section{INTRODUCTION}

The genus Zanthoxylum (Rutaceae) comprises some 549 species worldwide distributed. ${ }^{1}$ Economically, it has appreciable importance as a source of edible fruits, raw material for cosmetics and perfume industries, and by their culinary applications. ${ }^{2-4}$ Many species of Zanthoxylum have applications in traditional medicine especially in America, Africa and Asia. ${ }^{2-7}$ The leaves, bark and root bark of Z. ailanthoides Sieb. \& Zucc. have used as folk medicines in Taiwan and China to treat the common cold, stasis, contusions, snakebites and to stimulate blood circulation. ${ }^{5}$ Z. rhoifolium Lam has been popularly used in South America for inflammatory, microbial, cancerous and malaria processes. ${ }^{4,6}$

Chemical studies carried out on Zanthoxylum species have revealed the occurrence of alkaloids, lignans, amides and coumarins, of which some show fungitoxic potencial..$^{3-9}$ Extracts of some Zanthoxylum species shown significant antifungal activity. The bark methanol extract of Z. monophyllum showed significant activity against seven human pathogen fungi. ${ }^{10}$ The ethanolic extracts of leaves, fruits, steam bark and root of $Z$. americanum demonstrated a broad spectrum of antifungal and antibacterial activity against Candida albicans, Aspergillus fumigates, Cryptococcus neoformans and Fusarium oxysporum. ${ }^{11}$

Z. quinduense Tul. [syn. Fagara quinduense (Tul.) Engl., F. macrosperma (Tul.) Engl., Z. macrospermum (Tul.)] is a tree that grows in South America (Colombia, Venezuela, Ecuador and Peru). ${ }^{12}$ In previous publication we reported the presence of four benzophenanthridine alkaloids and one triterpene in its bark. ${ }^{13}$ The chemical constituents and biological activities of its wood have never been studied. As a continuation of our studies on this species, the present communication report the isolation and identification of the benzophenanthridine alkaloids, lignans, phenylpropens, benzenoids, sterols and fatty acids from wood of $Z$. quinduense; as well as the results of antifungal activity evaluated for the crude ethanolic extract, fractions and of the pure compounds.

\section{RESULTS AND DISCUSSION}

Chromatographic purification of the petroleum ether, dicloromethane and ethyl acetate fractions of the wood of Z. quinduense Tul. on silica gel column and preparative thin-layer chromatography (TLC)

*e-mail: ojpatinol@unal.edu.co afforded known compounds: norchelerythrine (1), 6-acetonyldihydrochelerythrine (2), p-hydroxybenzaldehyde (3), vanillic acid (4), evofilin $C$ (5), syringaresinol (6), decarine (7), mixture of sterols M1 [ $\beta$-sitosterol (8), stigmasterol (9) and campesterol (10)] and a mixture of saturated and unsaturated fatty acids, and their derived methyl esters M2. The compounds 1-7 were elucidated by spectroscopic techniques and comparison with the data described in the literature, and by comparison with authentic samples (TLC). The mixture of sterols M1 and fatty acids M2 were analyzed by GC/MS.

The compounds (1) and (7) gave positive to Dragendorff's reagent. Their ${ }^{1} \mathrm{H}$ NMR spectrum present the typical signals for benzophenanthridine alkaloids: two signals in the aromatic region enough displaced to low field due to the proximity of the nitrogen, one singlet characteristic of the proton attached to C-6 $\left[\delta_{\mathrm{H}} 9.74(1 \mathrm{H}, \mathrm{s})\right.$ to $(1)$ and $\delta_{\mathrm{H}} 9.63(1 \mathrm{H}$, s) to (7)] and another typical of the proton of the position $\mathrm{C}-4\left[\delta_{\mathrm{H}} 8.72\right.$ $(1 \mathrm{H}, \mathrm{s})$ to $(\mathbf{1})$ and $\delta_{\mathrm{H}} 8.66(1 \mathrm{H}, \mathrm{s})$ to $\left.(7)\right]$; singlet for a methylenedioxy group located on the positions C-2 and C-3 $\left[\delta_{\mathrm{H}} 6.13(2 \mathrm{H}, \mathrm{s})\right.$ to $(\mathbf{1})$ and $\delta_{\mathrm{H}}$ $6.19(2 \mathrm{H}, \mathrm{s})$ to $(7)]$. Also, the aromatic region of the ${ }^{1} \mathrm{H}$ NMR spectrum exhibited two pairs of one-proton doublets $\left[\delta_{\mathrm{H}} 8.35(1 \mathrm{H}, \mathrm{d}, J=9.0 \mathrm{~Hz}\right.$, $\mathrm{H}-11), 8.34$ (1H, d, $J=9.0 \mathrm{~Hz}, \mathrm{H}-10), 7.84(1 \mathrm{H}, \mathrm{d}, J=9.0 \mathrm{~Hz}, \mathrm{H}-12)$ and $7.59(1 \mathrm{H}, \mathrm{d}, J=9.0 \mathrm{~Hz}, \mathrm{H}-9)$ to $(\mathbf{1})$, and $\delta_{\mathrm{H}} 8.49(1 \mathrm{H}, \mathrm{d}, J=9.0 \mathrm{~Hz}$, $\mathrm{H}-11), 8.45$ (1H, d, $J=8.9 \mathrm{~Hz}, \mathrm{H}-10), 7.95$ (1H, d, $J=9.0 \mathrm{~Hz}, \mathrm{H}-12)$ and $7.61(1 \mathrm{H}, \mathrm{d}, J=8.9 \mathrm{~Hz}, \mathrm{H}-9)$ to $(7)]$. The coupling pattern for the aromatic protons indicated the substituents groups to be at the $\mathrm{C}-7$ and $\mathrm{C}-8$ position, similar to the chelerythrine. ${ }^{14}$ The similar ${ }^{1} \mathrm{H}$ and ${ }^{13} \mathrm{C}$ NMR data for rings A-D of (1) and (7) showed them to have the same substitution pattern. The only difference between (1) and (7) was the presence of an additional methoxyl group for (1) instead of hydroxyl group in (7). The position of the substituents and all non- hydrogenated carbons of (1) and (7) were achieved with the aid of the HMBC spectra. By comparison of the ${ }^{1} \mathrm{H}$ and ${ }^{13} \mathrm{C}$ NMR data of these compounds with the reported data in the literature, the identity of the compounds (1) and (7) were established as norchelerythrine and decarine, respectively. ${ }^{14,15}$

The compound (2) presents a similar structure to norchelerythrine (1) and decarine (7). In contrast to (1) and (7), the ${ }^{1} \mathrm{H}$ NMR spectrum showed typical aromatic signals for a benzophenathridine alkaloid with the chelerythrine substitution pattern (except signal characteristic of the proton attached to C-6) confirming that the compound is a dihydrochelerythrine substituted at C- 6 . The presence of an acetonyl group at C-6 was indicated by a singlet for a methyl group $\left(\delta_{\mathrm{H}} 1.97\right)$ and the AMX system $\delta_{\mathrm{H}} 2.25(1 \mathrm{H}, \mathrm{dd}, J=15.0,3.6 \mathrm{~Hz}), 2.61(1 \mathrm{H}$, dd, 
$J=15.0,11.2 \mathrm{~Hz})$ and $5.06(1 \mathrm{H}, \mathrm{dd}, J=11.2,3.6 \mathrm{~Hz}, \mathrm{H}-6)$ due to $\mathrm{H}-6$ and the acetonyl methylene protons in its ${ }^{1} \mathrm{H}$ NMR spectrum and signals at $\delta_{\mathrm{C}} 207.7(\mathrm{C}=\mathrm{O}), 31.0\left(\mathrm{COCH}_{3}\right)$ and $46.8\left(-\mathrm{CH}_{2} \mathrm{CO}\right)$ in the ${ }^{13} \mathrm{C}$ NMR spectrum. On the basis of this evidence, their optical rotation value, $[\alpha]^{25}{ }_{\mathrm{D}}-135^{\circ}\left(\mathrm{c} 0.13, \mathrm{CHCl}_{3}\right)$, and literature data the alkaloid was identified as (-)-6-acetonyldihydrochelerithrine (2). ${ }^{16}$

The ${ }^{1} \mathrm{H}$ NMR spectra of (5) show the characteristic pattern of 1,4-disubstituted benzenes with two first order doublets at $\delta_{\mathrm{H}} 7.31(2 \mathrm{H}$, d, $J=8.7 \mathrm{~Hz}, \mathrm{H}-2, \mathrm{H}-6)$ and $6.86(2 \mathrm{H}, \mathrm{d}, J=8.7 \mathrm{~Hz}, \mathrm{H}-3, \mathrm{H}-5)$. The chemical shifts of the aromatic protons indicate an oxy-substituent in the para-position to an alkyl group. The substituent can be identified as $3^{\prime}, 3^{\prime}$-dimethylallyloxyl group by the singlets for two methyl groups $\left[\delta_{\mathrm{H}}\right.$ $1.74\left(3 \mathrm{H}, \mathrm{s}, \mathrm{H}-4^{\prime}\right)$ and $\left.1.80\left(3 \mathrm{H}, \mathrm{s}, \mathrm{H}-5^{\prime}\right)\right]$ and an olefinic group $\left[\delta_{\mathrm{H}} 5.49\right.$ $\left.\left(1 \mathrm{H}, \mathrm{m}, \mathrm{H}-2^{\prime}\right)\right]$, and the doublet for a methylene group $\left[\delta_{\mathrm{H}} 4.50(2 \mathrm{H}, \mathrm{d}\right.$, $\left.\left.J=6.8 \mathrm{~Hz}, \mathrm{H}-1^{\prime}\right)\right]$ in its ${ }^{1} \mathrm{H}$ NMR spectrum and signals at $\delta_{\mathrm{C}} 18.2\left(\mathrm{CH}_{3}\right)$, $25.8\left(\mathrm{CH}_{3}\right), 64.8\left(\mathrm{OCH}_{2}\right), 119.6(\mathrm{CH})$ and $138.3(\mathrm{C})$ in the ${ }^{13} \mathrm{CNMR}$. The second substituent is a 3-hydroxy-1-propenyl moiety, with the typical pattern of an $\mathrm{ABC}$ system with resonances at $\delta_{\mathrm{H}} 6.55(1 \mathrm{H}$, br d, $J=15.9$ $\mathrm{Hz}, \mathrm{H}-7$ ), 6.23 (1H, dt, $J=15.9,6.0 \mathrm{~Hz}, \mathrm{H}-8$ ), and 4.29 (2H, dd, $J=6.0$, $1.0 \mathrm{~Hz}, \mathrm{H}-9$ ), for $-\mathrm{CH}=\mathrm{CH}-\mathrm{CH}_{2} \mathrm{OH}$. The large olefinic coupling constant is characteristic of a trans configurated double bond. Compound (5) therefore, was identified as the already known evofilin- $C .{ }^{17}$

In the same way, the substances (3) and (4) were identified as derived of the benzoic acid, $p$-hydroxybenzaldehyde and vanillic acid, respectively. These compounds have been previously isolated in $Z$. zanthoxyloides $^{18}$ and Z. schinifolium. ${ }^{19}$

(+)-Syringaresinol (6) was isolated as colorless oil from dichloromethane fraction. The ${ }^{1} \mathrm{H}$ NMR spectrum of (6) present the typical signals for bicyclooctane lignans: signals for the 3,3-O-bicyclooctane moiety with eight aliphatic protons $\left[\delta_{\mathrm{H}} 3.09(2 \mathrm{H}, \mathrm{m}, \mathrm{H}-1, \mathrm{H}-5), 3.91\right.$ $\left(2 \mathrm{H}, \mathrm{m}, \mathrm{H}-4_{\mathrm{ax}}, \mathrm{H}-8_{\mathrm{ax}}\right), 4.27\left(2 \mathrm{H}, \mathrm{dd}, J=9.0,6.4 \mathrm{~Hz}, \mathrm{H}-4_{\mathrm{eq}}, \mathrm{H}-8_{\mathrm{eq}}\right)$ and $4.72(2 \mathrm{H}, \mathrm{d}, J=4.5 \mathrm{~Hz}, \mathrm{H}-2, \mathrm{H}-6)]$. The coupling constants of $\mathrm{H}-2$ and $\mathrm{H}-6$ were $4.2 \mathrm{~Hz}$ and showed the relative configuration of $\mathrm{H}-1$ and $\mathrm{H}-2, \mathrm{H}-5$ and $\mathrm{H}-6$ to be trans-form. ${ }^{20}$ Also, the ${ }^{1} \mathrm{H}$ NMR spectrum exhibited a signals for tetrasubstituted benzene moieties each one with two methoxyl groups $\left[\delta_{\mathrm{H}} 3.88(6 \mathrm{H}, \mathrm{s})\right]$ and one hydroxyl group at $\delta_{\mathrm{H}}$ 5.57. The simplicity of the ${ }^{1} \mathrm{H}$ NMR spectrum revealed (6) to be a symmetrical lignan. With the dextrorotatory optical rotation, $[\alpha]_{\mathrm{D}}^{25}+41.6^{\circ}(c$ $\left.0.15, \mathrm{CHCl}_{3}\right)$, the structure of $(\mathbf{6})$ was elucidated as (+)-syringaresinol, which was further confirmed by ${ }^{13} \mathrm{C}$ NMR, DEPT, HMQC and HMBC spectra and by comparison of literature data. ${ }^{21}$

${ }^{1} \mathrm{H}$ and ${ }^{13} \mathrm{C}$ NMR analysis for mixture $\mathrm{M} 1$ and the comparison with literature data showed the presence of $\beta$-sitosterol $(\mathbf{8})$ and stigmasterol (9) in proportion of 10:1. However, the chromatogram of total ions of the analysis for it GC/MS showed three picks with retention times 49.7, 50.4 and $52.1 \mathrm{~min}$ and integrated area of 16.44, 4.55 and $79.02 \%$, respectively. The comparison of the mass spectra corresponding to each pick, with the reported in the literature suggested that they correspond to stigmasterol (9), campesterol (10) and $\beta$-sitosterol (8), respectively. ${ }^{22}$

Among the metabolites presented in the study, this is the first report on the occurrence of vanillic acid (3), p-hydroxybenzaldehyde (4), evofilin $C$ (5), decarine (7) and fatty acids in Z. quinduense. Other secondary metabolites have been previously reported in its wood and bark. $^{13,23}$

The mixture M2 was analized by GC and GC/MS. A total of 8 different compounds accounting for $77.51 \%$ were identified as: methyl palmitate $(2.51 \%)$, palmitic acid $(\mathrm{C} 16: 0 ; 32.81 \%)$, ethyl palmitate $(8.74 \%)$, margaric acid $(\mathrm{C} 17: 0 ; 8.01 \%)$, methyl stearate $(2.12 \%)$, oleic acid $\left(\mathrm{C} 18: 1, \Delta^{9} ; 6.84 \%\right)$, stearic acid $(\mathrm{C} 18: 0 ; 12.40 \%)$ and ethyl stearate $(4.02 \%)$.

All the classes of compounds reported in this work have been found in other species of Zanthoxylum (including Fagara). The sterols, fatty acids and benzenoids found are common in many plant families. The
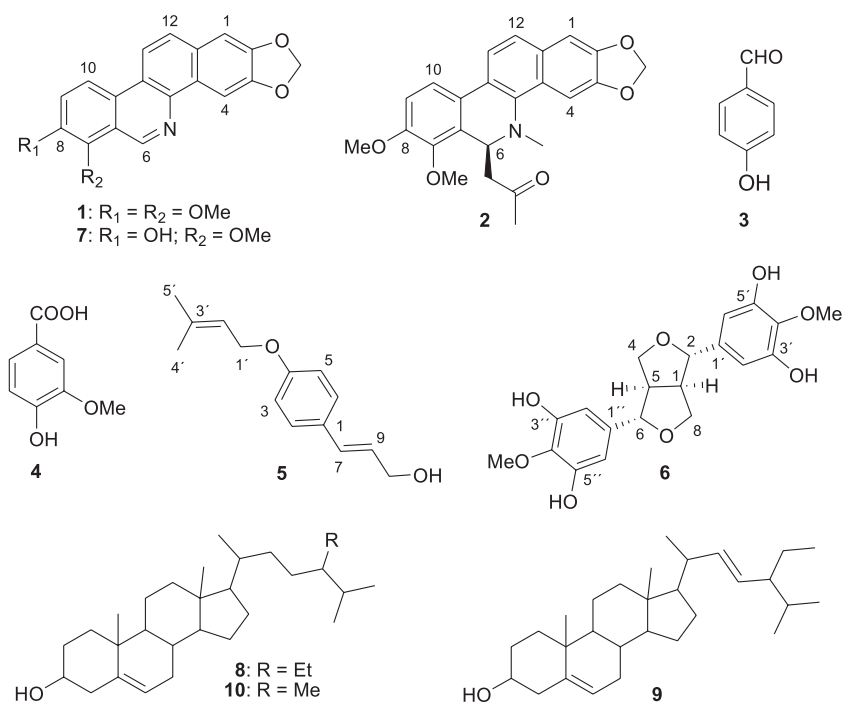

occurrence of evofilin $C(\mathbf{5})$ and syringaresinol (6) has been described in a large number of rutaceous plants including Zanthoxylum genus. Benzophenanthridine alkaloids have great chemotaxonomic importance since they are widely distributed throughout the genus but not in the Rutaceae family. ${ }^{8,14}$

The antifungal activity was evaluated by means of direct bioautography in a TLC bioassay. ${ }^{24}$ The ethanolic extract and its fractions (petroleum ether, dichloromethane, ethyl acetate and acetone) were inactive against Fusarium oxysporum f. sp. lycopersici. The inhibitory activity against the growth of the fungi was appreciable at $25 \mu \mathrm{g}$ for evofilin $C(\mathbf{5})$ and at $50 \mu \mathrm{g}$ for norchelerythrine (1), while the other compounds were ineffective.

\section{EXPERIMENTAL}

\section{General procedures}

Optical rotations were measured on a Schmidt-Haensch polarimeter. ${ }^{1} \mathrm{H}$ and ${ }^{13} \mathrm{C}$ NMR spectra as well as $2 \mathrm{D}$ spectra (COSY, HMQC, and HMBC) were recorded on a Bruker Avance 400 spectrometer operating at $400 \mathrm{MHz}$ for ${ }^{1} \mathrm{H}$ and $100 \mathrm{MHz}$ for ${ }^{13} \mathrm{C}$ using the solvent peaks as internal references. Silica gel (Merck, 230-400 mesh) was employed in the column chromatography separations, while silica gel $60 \mathrm{PF}_{254}$ (Merck) was used for analytical $(0.25 \mathrm{~mm})$ and preparative TLC $(1.0$ $\mathrm{mm}$ ). The visualization of the compounds was carried out with iodine vapors, UV light or Dragendorff's reagent.

The GC/MS analyses were performed in EI mode on a Hewlett Packard-5890 GC system with a fused capillary column $(50 \mathrm{~m} \times 0.25$ $\mathrm{mm} \times 0.25 \mu \mathrm{m}$, HP-5MS, Crossbond $5 \%$ phenyl-95\% dimethylpolysiloxane) directly coupled to on Hewlett Packard 5973 selective mass detector. Conditions of injection were the following: injector temperature $250{ }^{\circ} \mathrm{C}$; oven temperature program of $45(2 \mathrm{~min})-150^{\circ} \mathrm{C}(5 \mathrm{~min})$ at a rate of $2{ }^{\circ} \mathrm{C} / \mathrm{min}, 150{ }^{\circ} \mathrm{C}(2 \mathrm{~min})-280^{\circ} \mathrm{C}(5 \mathrm{~min})$ at a rate of $8{ }^{\circ} \mathrm{C} /$ min; split 30:1 during $1.50 \mathrm{~min}$, carrier gas He: $1 \mathrm{~mL} / \mathrm{min}$, constant flow; sample volume $1 \mu \mathrm{L}$. The mass spectrometer was operated at 70 $\mathrm{eV}$. The samples ware prepared dissolving $1 \mathrm{mg}$ of each sample in 1 $\mathrm{mL}$ of chloroform. The identification of the chemical constituents was based on comparison of their mass spectral pattern with those obtained from the Wiley 138.L and NBS 75K.L libraries.

\section{Plant material}

The wood of Z. quinduense Tul. was collected from the town of Albán, Cundinamarca, Colombia, in August 2005. The plant sample 
was identified by Adolfo Jara of the Herbario Nacional Colombiano of the Universidad Nacional de Colombia, and a voucher specimen of Z. quinduense Tul. (COL-511101) was deposited at the Herbario Nacional Colombiano of the Universidad Nacional de Colombia, Bogotá, Colombia.

\section{Extraction and isolation}

Dried and powdered wood $(4550 \mathrm{~g})$ of $Z$. quinduense was extracted by maceration successively with ethanol at room temperature. The resulting solutions were concentrated in vacuum to yield a crude extract $(81.4 \mathrm{~g})$ which was submitted to successive extraction by Soxhlet with petroleum ether (EP), dichloromethane $\left(\mathrm{CH}_{2} \mathrm{Cl}_{2}\right)$, ethyl acetate (EtOAc), and acetone ( $\left.\mathrm{Me}_{2} \mathrm{CO}\right)$ solvents. Concentration of solvents yielded $\mathrm{EP}$ fraction $(9.5 \mathrm{~g}), \mathrm{CH}_{2} \mathrm{Cl}_{2}$ fraction $(6.5 \mathrm{~g})$, EtOAc fraction $(2.0 \mathrm{~g})$ and $\mathrm{Me}_{2} \mathrm{CO}$ fraction $(12.2 \mathrm{~g})$.

Approximately, $7 \mathrm{~g}$ of the EP fraction was fractioned by column chromatography on silica gel, eluted with a mixture of EP:AcOEt at increasing polarity (9:1 to 5:5), to yield 16 fractions. In the fraction 1 (552.9 mg) denominated M1, analyzed by GC and GC/MS, was determined the occurrence of saturated and unsaturated fatty acids and their esters derivates. Fraction 8 (1.7 g), by successive washing with acetone, yield a white solid $(440.9 \mathrm{mg})$ that correspond to a mixture M2 of sterols known as $\beta$-sitosterol (8), stigmasterol (9) and campesterol (10).

The supernatant from 8 was put together with fraction 9 and submitted to repeat column chromatography on silica gel, using $\mathrm{C}_{6} \mathrm{H}_{6}:$ EtOAc (7:3) and $\mathrm{C}_{6} \mathrm{H}_{5} \mathrm{CH}_{3}$ :EtOAc (7:3) as elution systems. Then, two benzophenanthridine alkaloids, norchelerythrine (1) $(3.3 \mathrm{mg})$ and 6-acetonyldihydrochelerythrine $(2)(4.0 \mathrm{mg})$, were obtained by preparative TLC on silica gel, eluted with $\mathrm{CH}_{2} \mathrm{Cl}_{2}: \mathrm{MeOH}: \mathrm{HCOOH}$ (95:5:0.5) and $\mathrm{C}_{6} \mathrm{H}_{5} \mathrm{CH}_{3}$ : $\mathrm{EtOAc} / \mathrm{HCOOH}$ (95:5:0.5), respectively.

The $\mathrm{CH}_{2} \mathrm{Cl}_{2}$ and EtOAc fractions $(7.5 \mathrm{~g})$ were assembled and fractioned by column chromatography using a mixture of $\mathrm{C}_{6} \mathrm{H}_{5} \mathrm{CH}_{3}$ : EtOAc at increasing polarity (8:2 to $3: 7)$ to yield 14 fractions. Fraction 3 (102.7 $\mathrm{mg}$ ) afforded norchelerythrine $(4)(8.0 \mathrm{mg})$ by column chromatography eluting with mixture of $\mathrm{C}_{6} \mathrm{H}_{5} \mathrm{CH}_{3}$ :EtOAc (8:2). Fraction $5(357.3 \mathrm{mg})$ was submitted to column chromatography eluting with mixture of $\mathrm{C}_{6} \mathrm{H}_{5} \mathrm{CH}_{3}:$ EtOAc (9:1), then by preparative TLC, eluting with mixture of $\mathrm{CH}_{2} \mathrm{Cl}_{2}: \mathrm{MeOH}$ (98:2), were isolated vanillic acid (3) (17.6 mg), $p$ hydroxybenzaldehyde (4) $(24.3 \mathrm{mg})$ and mixture of evofilin $C(\mathbf{5})$ and $\beta$-sitosterol (8) (7.3 mg; 10:7). Fraction 8 (570.4 mg) was submitted to column chromatography, eluting with mixture of $\mathrm{CHCl}_{3}: \mathrm{MeOH}$ $(98: 2)$ to yield syringaresinol $(6)(62.7 \mathrm{mg})$ and decarine $(7)(4.0 \mathrm{mg})$.

\section{Antifungal assay}

The antifungal activity of the crude plant extract, fractions and pure compounds against Fusarium oxysporum f. sp. lycopersici was determined using the bioautographic technique. The microorganism used in the antifungal assay has been maintained at the Universidad Nacional de Colombia - Bogotá (Faculty of Science, Department of Chemistry, Laboratory of Vegetal Natural Products). Ten microliters of the solutions were prepared, in different concentrations, corresponding to $100,50,25,10,5,2$ and $1 \mu \mathrm{g}$ for pure compounds, and $300 \mu \mathrm{g}$ for the crude extract or fractions. The samples were applied to TLC plates, only extract and fractions were eluted with $\mathrm{CHCl}_{3}-\mathrm{MeOH}$ (95:5) or $n$-hexane-EtOAc (8:2) followed by complete removal of the solvent at room temperature.

The chromatograms were then sprayed with a spore suspension of fungi in glucose and salt solution and incubated for $72 \mathrm{~h}$ in the darkness in a moistened chamber at $25^{\circ} \mathrm{C}$. Exposure of TLC plates to UV light
(254 nm) and iodine vapours significantly enhanced contrast in order to detect inhibition zones, indicating the inhibitory activity against the growth of the fungi. Benomyl was used as positive control $(1 \mu \mathrm{g})$, and the solvents used to dissolved the samples were the negative controls. ${ }^{24}$

\section{AKCNOWLEDGMENTS}

The authors thank to Colciencias and to the Universidad Nacional de Colombia for financial support. Also thank to Nuclear Magnetic Resonance Laboratory at Universidad Nacional de Colombia for recording of RMN spectra and to Colombian Herbario Nacional Colombiano of the Universidad Nacional de Colombia for plant identification.

\section{REFERENCES}

1. http://data.gbif.org/species/13193794, accessed on April 2010.

2. Yang, X.; J. Agric. Food Chem. 2008, 56, 1689.

3. Adesina, S. K.; Afr. J. Trad. CAM. 2005, 2, 282.

4. Da Silva, S. L.; Figueredo, P. M. S.; Yano, T.; Pharmac. Biol. 2006, 44, 657.

5. Cheng, M.-J.; Tsai, I.-L.; Chen, I.-S.; J. Chin. Chem. Soc. 2003, 50, 1241.

6. Jullian, V.; Bourdy, G.; Georges, S.; Maurel, S.; Sauvain, M.; J. Ethnopharm. 2006, 106, 348.

7. Silva, C. V.; Detoni, C. B.; Velozo, E. S.; Guedes, M. L. S.; Quim. Nova 2008, 31, 2052.

8. Waterman, P. G.; Grundon, M. F.; Chemistry and Chemical Taxonomy of the Rutales, Academic Press: London, 1983; Mester, I.; Fitoterapia 1973, 44, 123.

9. Simeón, S.; Rios, J. L.; Villar, A.; Pharmazie 1989, 44, 593.

10. Gómez, Y.; Gil, K.; González, E.; Farías, L. M.; J. Trop. Biol. 2007, 55, 767.

11. Bafi-Yeboa, N. F. A.; Arnason, J. T.; Baker, J.; Smith, M. L. Phytomedicine 2005, 12, 370 .

12. http://data.gbif.org/species/15831350, 2009-02-24), accessed on April 2010.

13. Patiño, O. J.; Cuca, L. E.; Rev. Colomb. Quim. 2004, 33, 13.

14. Krane, B. D.; Fagbule, M. O.; Shamma, M.; J. Nat. Prod. 1984, 47, 1.

15. Martín, M. T.; Rasoanaivo, L. H.; Raharisololalao, A.; Fitoterapia 2005, 76, 590 .

16. Martinez-Martinez, F. J.; Padilla-Martinez, I. I.; Hernandez-Carlos, B.; Perez-Gutierrez, R. M.; Garcia-Baez, E. V.; J. Chem. Crystallogr. 2002, 32,63 .

17. Brader, G.; Bacher, M.; Hofer, O.; Greger, H.; Phytochemistry 1997, 45, 1207.

18. Ouattara, B.; Angenot, L.; Guissou, P.; Fondu, P.; Dubois, J.; Frederich, M.; Jansen, O.; Heugen, J.-C.; Wauters, J.-N.; Tits, M.; Phytochemistry $\mathbf{2 0 0 4}, 65,1145$

19. Cheng, M.-J.; Yang, C.-H.; Lin, W.-Y.; Tsai, I.-L.; Chen, I.-S.; J. Chin. Chem. Soc. 2002, 49, 125.

20. Miyazawa, M.; Ishikawa, Y.; Kasahara, H.; Yamanaka, J. I.; Kameoka, H. Phytochemistry 1994, 35, 611; Greger, H.; Hofer, O.; Tetrahedron 1980, $36,3551$.

21. EI-Hassan, A.; El-Sayed, M.; Hamed, A.I.; Rhee, I. K.; Ahmed, A. A.; Zeller, K. P.; Verpoorte, R.; Fitoterapia 2003, 74, 184.

22. Rocha, H. S.; Silva, C. C. M.; Caland Neto, L. B.; Lopes, J. A. D.; Citó, A. M. G. L.; Chaves, M. H.; Quim. Nova 2007, 30, 1877.

23. Patiño, O. J.; Cuca, L. E.; Scientia et Technica 2007, 33, 171.

24. Marques, J. V.; Saga, R. O. K.; Lago, J. H. G.; Young, M. C. M.; Guimarães, E. F.; Kato, M. J.; J. Nat. Prod. 2007, 70, 2036; Homans, A. L.; Fuchs, A.; J. Chromatogr. 1970, 51, 327. 